\title{
Література:
}

1. Гаврильців С. Т. Цитокіновий статус у хворих із різним типом запальної реакції при нагноєнні радикулярних кіст нижньої щелепи. Клінічна стоматологія. 2013. № 3-4. С. 92-93.

2. Кузняк Н. Б. Хірургічне лікування радикулярних кіст з використанням біокомпозиційних матеріалів. Клінічна стоматологія. 2014. № 3. C. 19-22.

3. Changes in quality of life following third molar. African Health Sciences. 2011. Vol. 11(3). P. 265-268.

4. Guerrero M. E. Can preoperative imaging help to predict postoperative outcome after wisdom tooth removal? A randomized controlled trial using panoramic radiography versus cone-beam CT. Clinical oral investigations. 2013. Vol. 8. P. 264-268.

5. Halpern L. R. Does prophylactic administration of systemic antibiotics prevent postoperative inflammatory complications after third molar surgery? Journal of Oral and Maxillofacial Surgery. 2007. Vol. 65 (2). P. 177-185.

6. Тимофеев А. А. Использование препарата «Гивалекс» после проведения костнопластических операций. Современная стоматология. 2013. № 4. С. 116-121.

7. Кіщук В. В. Сучасна тактика місцевого лікування хворих на гострий фарингіт та загострення хронічного фарингіту. Журн. Вушних, носових і горлових хвороб. 2010. № 5. С. 54-56.

DOI https://doi.org/10.30525/978-9934-588-81-5-1.31

\section{DESTRUCTIVE FORMS OF ACUTE APPENDICITIS IN CHILDREN}

\author{
Korobko Y. Ye. \\ Assistant Lecturer at the Department of Children Surgery \\ National Pirogov Memorial Medical University, Vinnytsia \\ Vinnytsia, Ukraine
}

The aim: to analyze the causes of destructive forms of acute appendicitis based on the study of the characteristics of pathology in children of Vinnytsia region (Ukraine) in the period from 2005 to 2018.

Materials and methods. We made a retrospective analysis of 980 medical records of patients treated at the Vinnytsia Regional Clinical Hospital 
with destructive forms of acute appendicitis in the period $2005-2018$. The age of children - from 1.5 to 18 years.

The topic of acute appendicitis is relevant today. Acute appendicitis is a very common inflammatory disease of the abdominal cavity. In developed countries, the incidence of acute appendicitis is from $4-6 \%$ to $12-23 \%$, in Ukraine - 20-21 cases per 10 thousand population, mostly in young people [1]. In the United States and Europe, the incidence of acute appendicitis in the population reaches 7-12\%. [2] Annually in the United States perform about 60 thousand appendectomies in children, in the UK - up to 40 thousand, in Russia - more than 220 thousand, the mortality rate is $0.13 \%$ [3]. Acute appendicitis is most often diagnosed at the age of $10-19$ years [4].

Criteria for selecting patients for the study: late requesting for treatment (later than 24 hours); destructive forms of acute appendicitis (according to the results of histological examinations); the absence of any other concomitant acute inflammatory pathology of the abdominal organs.

Comprehensive analysis of examinations of sick children took into account: study of anamnesis data; clinical examination of patients; radiological examination data, ultrasound examination and spiral computed tomography of the abdominal cavity; laboratory tests - general analysis of blood and urine, blood electrolytes, data from microbiological studies of effusion from the abdominal cavity to determine sensitivity to antibiotics; morphological examination of materials removed from the body.

During the analysis in the period 2005 - 2018 in Vinnytsia Regional Children's Clinical Hospital 980 children with destructive forms of acute appendicitis were operated. It was found that boys (55.3\%) most often suffered from destructive forms of acute appendicitis, the percentage of pathology in girls was slightly lower and amounted to $44.7 \%$ (431 people), which is most likely due to the higher frequency of appeals to doctors, especially pediatric gynecologists, in connection with the awareness of the danger of possible complications of reproductive function in the future. At the place of residence, children with destructive forms of acute appendicitis were more common among urban residents $-61.2 \%$ (598 people) than among rural residents $-38.8 \%$ (372 people). The study also showed that significantly more destructive forms of acute appendicitis occur in older children (aged $11-17$ years - 537 patients (55\%) had destructive appendicitis, in children aged $3-10$ years the disease was detected in 394 patients (40\%). The smallest group where acute appendicitis was detected is the younger age group $(0-3$ years $)-49$ children $(5 \%)$. 
Examining the period of requesting to the doctor, it was found that patients with destructive forms of acute appendicitis were hospitalized later than one day from the onset of the disease $-44.8 \%$ (431 patients), on the second day the disease was diagnosed in $34.9 \%$ (333 patients), on the third day - in $15.2 \%$ (147 patients), later on the 3rd day - in 5.1\% (49 patients).

The main reasons for late admission to a surgical hospital were: selfmedication (taking antispasmodics, analgesics, sorbents, antibiotics, etc.), diagnostic errors at the primary level, the distance of the settlement from hospitals, low level of self-education, etc.

In the postoperative period, the following complications were noted: $58.2 \%$ (586 people) - local peritonitis, 38.4\% (372 people) - diffuse peritonitis and $3.4 \%$ (29 people) - total peritonitis.

Conclusions. The structure of the incidence of destructive forms of acute appendicitis is dominated by male patients aged $11-17$ years. The main reasons for late medical treatment were self-medication and diagnostic underdevelopment at the primary care level. The structure of complications of acute appendicitis was dominated by local peritonitis.

The most important way to improve the methods of diagnosis of acute appendicitis is to find specific diagnostic methods that would be simple and inexpensive to use and as informative as possible to supplement the clinical examination. Sanitary and educational work among the population on the possible causes of abdominal pain will also contribute to the timely diagnosis of this disease and avoid complications.

\section{References:}

1. Barsukova I. M., Gavschuk M. V., Krivov A. P. Ostryiy appenditsit: istoriya i sovremennaya organizatsiya meditsinskoy pomoschi. Uchenyie zapiski SPBGMU im. akad. I. P. Pavlova, 2018 25(3); 43-49. DOI: 10.24884/1607-4181-2018-25-3-43-49.

2. Ivanko O. V., Kalyna R. A. Problemy ta napriamy suchasnoho likuvannia hostroho apendytsytu. Khirurhiia Ukrainy, 2014. 3; 100-104.

3. Peter M, Peter F. N., Michael D. R., Christopher S. M. Fundamentals of Pediatric Surgery: education manual. Switzerland. Springer 935, 2017.

4. Cesare A. D., Parolini F., Morandi A., Leva E., Torricelli M. Do we need imaging to diagnose appendicitis in children? Afr. J. Paediatr. Surg, 2013. 10(2); 58-73. doi: 10.4103/0189-6725.115024. 